\title{
European decision support modelling of long-term external doses received in inhabited areas contaminated by a nuclear power plant accident - 1: Initial relative dose rate contributions from different contaminated outdoor surfaces
}

\author{
Hinrichsen, Yvonne; Andersson, Kasper Grann
}

Published in:

Journal of Environmental Radioactivity

Link to article, DOI:

10.1016/j.jenvrad.2019.04.008

Publication date:

2019

Document Version

Peer reviewed version

Link back to DTU Orbit

Citation (APA):

Hinrichsen, Y., \& Andersson, K. G. (2019). European decision support modelling of long-term external doses received in inhabited areas contaminated by a nuclear power plant accident - 1: Initial relative dose rate contributions from different contaminated outdoor surfaces. Journal of Environmental Radioactivity, 204, 143153. https://doi.org/10.1016/j.jenvrad.2019.04.008

\section{General rights}

Copyright and moral rights for the publications made accessible in the public portal are retained by the authors and/or other copyright owners and it is a condition of accessing publications that users recognise and abide by the legal requirements associated with these rights.

- Users may download and print one copy of any publication from the public portal for the purpose of private study or research.

- You may not further distribute the material or use it for any profit-making activity or commercial gain

- You may freely distribute the URL identifying the publication in the public portal 


\title{
European decision support modelling of long-term external doses received in inhabited areas contaminated by a nuclear power plant accident -1 : initial relative dose rate contributions from different contaminated outdoor surfaces
}

\author{
Yvonne Hinrichsen and Kasper G. Andersson* \\ Technical University of Denmark, Center for Nuclear Technologies, DK-4000 Roskilde, Denmark \\ *Corresponding author: kgan@dtu.dk
}

\begin{abstract}
Dose prediction tools making use of existing knowledge on the environmental behaviour of radiocontaminants are essential for justification and optimisation of recovery countermeasure strategies for contaminated inhabited areas. In this context, one necessary requirement is to estimate the relative initial contaminant distribution on different types of surfaces in the environment and the resultant initial dose rates to humans staying in the environment. This paper reports on the latest parametric refinements in this context for use in the ERMIN inhabited area dose model, which is an integral part of the European emergency management decision support systems ARGOS and RODOS.
\end{abstract}

\section{Introduction}

Prior to 1986, it was in general thought that any significant airborne environmental contamination resulting from nuclear power plant accidents would be restricted to rural areas very near the power plant. However, the Chernobyl accident demonstrated that inhabited environments and even cities at considerable distances from the release point could become strongly affected. On the basis of the measurements and learning points after the Chernobyl accident, relatively simple calculation models were soon created to enable rough estimation of the external doses to urban and suburban populations (e.g., Crick \& Brown, 1989; Andersson, 1989). Subsequently these models were integrated with the much more comprehensive map based decision support systems ARGOS (2018) and RODOS (2018), which are today support emergency arrangements in practically all European countries as well as in, e.g., Canada, Brazil and Australia. Over the following decades, the common model for external dose in inhabited areas in the ARGOS and RODOS systems, known as the ERMIN (EuRopean Model for INhabited areas) model co-developed and coded at Public Health England (Charnock, 2018; Andersson et al., 2009; Charnock et al., 2009; Andersson et al., 2008), has been developed and considerably refined, for example through extended studies of long-term natural weathering parameter components of contaminants on different types of surface, and conceptual improvements (including representation of weather conditions and contaminant characteristics). Recently, the ERMIN databases were revised and updated again in the European projects PREPARE and CONFIDENCE to accommodate the newest available information, and expand the scope so that contaminant particles of a range of relevant characteristics can now be modelled (previously only two types could be modelled: $0-2$ $\mu \mathrm{m}$ and 2-5 $\mu \mathrm{m}$; Jones et al., 2007), and also rough estimates of uncertainties of relevant parameters in ERMIN have been addressed. This paper reports on the latest developments in relation to identification of the relative contamination levels on different outdoor surfaces in the inhabited environment and the air kerma rates that the presence of these contaminants would imply in different positions in an inhabited environment. In part 2 of the paper, the post-deposition mobility of contaminants on/in these surfaces in 
the inhabited environment and the importance of all the described methods and parameters for external dose prognoses are dealt with.

\section{Materials and methods}

Model estimation of deposition of contaminants may be useful for several purposes in nuclear emergency management decision support, including rough early phase external dose prognoses when local measurements of deposits on different representative surfaces have not yet been made, drills and competence building training sessions to assess possible consequences of different contamination scenarios and possibly to dimension an operational preparedness accordingly (e.g., assess recovery capability and capacity).

The deposition is greatly dependent on the physicochemical properties of the contaminants and the types and orientations of the surfaces in the inhabited area to which the deposition occurs (Andersson, 2009). It should thus first be considered which physicochemical forms the various likely contaminants from a major NPP (nuclear power plant) accident could be expected to have. A 'consensus' list of contaminants considered potentially important by Slovakia, France, Germany, Finland, Czech Rep. and USA for evaluation of radiological consequences in case of severe NPP accidents comprises (apart from noble gases) radionuclides of the following elements: $\mathrm{Am}, \mathrm{Ba}, \mathrm{Ce}, \mathrm{Cs}, \mathrm{Cm}, \mathrm{I}, \mathrm{La}, \mathrm{Mo}, \mathrm{Nb}, \mathrm{Np}, \mathrm{Pu}, \mathrm{Rb}, \mathrm{Ru}, \mathrm{Sb}, \mathrm{Sr}, \mathrm{Te}$ and $\mathrm{Zr}$ (Andersson et al., 2013). The physicochemical forms of these in future accidental releases will depend on a complex of processes and conditions during the release, and are difficult to predict. However, the experience from history's two large nuclear power plant accidents, the Fukushima and the Chernobyl accident, provide very useful information on what might be expected in some different types of scenarios, and for instance which sizes, materials and thus aerodynamic behaviour the produced aerosols might be expected to have under different conditions. A literature search has been made in this study on the characteristics of radiocontaminants that might be released to the environment in a nuclear power plant accident, and on which relative initial contamination levels on different surfaces in the inhabited environment would be likely to occur for contaminants with different characteristics.

By multiplication of initial relative contamination levels with dose rate conversion factors (dose rate in a given environmental location per photon emitted with a given energy per unit area of each contaminated surface), the initial relative dose rate contributions to persons staying in given types of inhabited areas from different contaminated surfaces in the area can be estimated. Apart from drills and training purposes, detailed dose rate modelling is an essential requirement in estimating any future doses to people living in a contaminated area, as these can obviously not be measured (e.g., residual doses when considering different recovery intervention strategies on different contaminated surfaces; ICRP, 2007).

After the contamination levels on different surfaces in an inhabited area from the passage of the contaminated plume have been estimated, an important next step in determining the associated long-term external doses to affected populations is to relate the contamination levels to dose rates to people present in different locations in different representative inhabited environments. Depending on the types and energies of the radiation, and the positions of people in the environment over time in relation to contaminated and shielding surfaces, dose rates per unit surface contamination on a given surface can vary 
very widely. Due to the geometrical complexity of inhabited environments with potentially highly shielding structures and, e.g., low-shielding window areas that can vary considerably in number, location and size, simple point kernel models are inadequate in predicting resultant dose rates (Jensen and Thykier-Nielsen, 1989). Instead, the Monte Carlo method can be used to randomly model the propagation in a given environment of a large number of individual photons and probabilistically track their paths as they collide with atoms and cause secondary radiation in the media they pass through. Resultant dose rates can then be computed in various points in the environment, which might be occupied by humans. The most widely used, extensively validated and suitable Monte Carlo code available for calculation of complex gamma fields is probably the MCNP developed at Los Alamos National Laboratory in the USA (Goorley et al., 2012; Lin et al., 2011), and this was selected for the studies reported in this paper.

\section{Results}

\subsection{Relative deposition of contaminants on different surfaces in inhabited areas}

To shed light on possible physicochemical forms of different contaminants potentially released in a nuclear power plant accident, the experience from the Chernobyl and Fukushima accidents was first assessed.

The radionuclide composition of released contaminants will depend on the source, while contaminant characteristics such as particle/gas release fractions, particle size distribution, solubility and oxidation states will also depend on the release processes, in particular on the temperature, pressure and the presence of air/oxygen (Lind, 2006; Lind et al., 2009; Salbu, 2001).

One of the most volatile contaminants (except noble gases) is iodine, which may be released in its elemental gas form (which has a very high deposition velocity to surfaces), in organic gas forms (where the deposition velocity is comparatively insignificant and thus in practice unimportant), and as condensed vapour on ambient aerosols, typically resulting in an AMAD (activity median aerodynamic diameter) in the range of 0.5-1 $\mu \mathrm{m}$, which would have an intermediate deposition velocity (Andersson, 2009). As expected, comparatively very high release fractions of iodine were reported in connection with both the Chernobyl (0.2; IAEA, 1991) and Fukushima (0.1; IAEA, 2015) accidents. Iodine aerosol spectra obtained at different distances after the Chernobyl accident show a perfect Gaussian distribution with no signs of bimodality (e.g., Reineking et al., 1987; Jost et al., 1986), with an AMAD of about $0.5 \mu \mathrm{m}$, which is slightly smaller than that of the corresponding $\mathrm{Cs}$ aerosol. This iodine aerosol size distribution compares well with that registered after the Fukushima accident (Kaneyasu et al., 2012). However in these measurements the size distribution is a complete match with that for caesium, indicating that insignificant quantities of larger (fuel fragment) particles containing traces of caesium were at the times of measurement released at Fukushima. This suggests that the aerosol iodine can essentially be assumed to be purely condensed mode (on ambient particles). This is in-line with the high solubility and initial post-deposition mobility recorded for all the deposited iodine from Chernobyl at different distances (see, e.g., Roed, 1990). It should be noted that measurements by Hirose (2016) suggest that the Cs aerosol was over a limited period of time somewhat larger (1.5-1.8 $\mu \mathrm{m})$, possibly reflecting significantly different processes of local ambient particle generation.

At the other end of the volatility spectrum, in the Chernobyl accident, contaminants of certain elements were only released to the atmosphere in the form of comparatively large low solubility fuel particles, 
indicating that these would in general be expected to be highly refractory (undepleted from the fuel). These elements comprised ${ }^{95} \mathrm{Zr},{ }^{95} \mathrm{Nb},{ }^{140} \mathrm{Ba},{ }^{140} \mathrm{La},{ }^{141 / 144} \mathrm{Ce},{ }^{237 / 239} \mathrm{~Np},{ }^{238-242} \mathrm{Pu},{ }^{241 / 243} \mathrm{Am}$ and ${ }^{242 / 244} \mathrm{Cm}$ (Bobovnikova et al., 1990, Loschilov et al., 1992, Kuriny et al., 1993, Kashparov et al., 2003; Salbu et al., 1994). They were not reported after the Fukushima accident where the explosions were less powerful but it cannot be ruled out that future accident scenarios might lead to releases of fuel particles. Apart from the fuel particles with sizes allowing them to follow air streams, part of the released fuel from the Chernobyl accident was in the form of either very large fuel fragments spread ballistically by the power of the release process, or very large conglomerates of nuclear fuel fused with melted zirconium (Kashparov et al., 2003). This part of the contamination was mainly in a form with a size range from several tens to more than a thousand microns (Kashparov et al., 2003), and mostly deposited within the nearest $2 \mathrm{~km}$ (Kashparov et al., 2003) - a zone where it makes absolutely no sense to attempt to model the contaminant distribution through atmospheric dispersion modelling. These huge particles/fragments, although probably locally dominant in some areas over very small distances, are estimated to contain only a small fraction of the total contamination (Kashparov et al., 1999). It can thus be assumed that nearly all atmospherically dispersed particles carrying $\mathrm{Zr}, \mathrm{Nb}, \mathrm{Ba}, \mathrm{La}, \mathrm{Ce}, \mathrm{Np}, \mathrm{Pu}, \mathrm{Am}$ and $\mathrm{Cm}$ are aerosol-sized fuel particles. Measurements made after the Chernobyl accident showed that the smallest of these particles (which reached great distances) had a size of about $4 \mu \mathrm{m}$ (Reineking et al., 1987; Rulik et al., 1989, Mala et al., 2013). Kashparov et al. $(1996,1999)$ reported of a fuel aerosol particle median diameter of some 5-6 $\mu \mathrm{m}$ corresponding to a crystallite size of the fuel. This actually seems consistent with results of smaller explosive tests (although clearly much less powerful) interacting on a matrix of uranium dioxide (Harper et al., 2007), where the smallest particles were found to be some $4 \mu \mathrm{m}$, but the greatest part of the aerosolised mass was in the ca. 5-20 $\mu \mathrm{m}$ range. In addition to pure fuel (uranium oxides) particles, also fuel mixes with construction materials and fire extinguishing materials have been reported in the near zones after the Chernobyl accident, which could have a different environmental mobility (Dobrovolsky \& Lyalko, 1995; Lind, 2006).

Relatively large fractions of $\mathrm{Cs}, \mathrm{Te}$ and $\mathrm{Rb}$ (and somewhat smaller fractions of $\mathrm{Sb}$ and $\mathrm{Mo}$ ) were released in the Fukushima accident (Le Petit et al., 2014) and the Chernobyl accident (IAEA, 1991), and these should, based on Chernobyl data (e.g., Bobovnikova et al., 1990, Loschilov et al., 1992, Kuriny et al., 1993) be expected to a considerable extent (probably somewhat less for Sb and $\mathrm{Mo}$ ) to be volatilised from the fuel, forming submicroneous condensation particles. In the Chernobyl case with powerful explosions, investigations by Kuriny et al. (1993) show that even at distances up to about 50-60 km in some directions from the Chernobyl NPP, most of the deposited caesium was in the form of fuel particles. This agrees with results of experimental investigations of the effect of decontamination operations (water hosing on impermeable surfaces) carried out in Pripyat and hundreds of km away from the Chernobyl NPP, where the contamination was much easier removed in the nearest areas where it was associated with large lowsolubility fuel particles (Andersson, 2009). The data of Salbu et al. (1994) show that the relationship between ${ }^{90} \mathrm{Sr}$ and ${ }^{137} \mathrm{Cs}$ in fuel particle deposition dominated areas was roughly 10 times higher than that in condensation particle deposition dominated areas. This can be taken as an indication that the fuel particles may have been depleted about 10 times more with respect to Cs than with respect to Sr. Some association with fuel particles could explain the slightly bimodal ${ }^{137} \mathrm{Cs}$ aerosol distribution measured by Reineking et al. (1987) as far away as Göttingen in central Germany after the Chernobyl accident, clearly showing the presence of some supermicron particles, which would be expected to have low solubility (Andersson, 
2009). Again, the depletion fraction would be expected to vary according to the exact accident scenario conditions. The caesium aerosol measured after the Fukushima accident was generally submicron and characteristic of condensation mode (Kaneyasu et al., 2012), even though surprising processes some days after the start of the Fukushima accident also seem to have resulted in creation of some homogeneously caesium-containing spherical low solubility particles in the $2 \mu \mathrm{m}$ range (Adachi et al., 2013). Caesium has also been reported in association with particles of this size range with very high specific activity lkehara et al. (2019). The quantity and thus significance of such particles has not been determined. In connection with the Chernobyl accident, single element particles (e.g., ruthenium, caesium) were recorded more than a thousand $\mathrm{km}$ from Chernobyl (Salbu, 1988), indicating the complexity of processes during the release.

As for strontium, both fuel particle and small condensation aerosol fallout has been reported from the Chernobyl accident (Kashparov et al., 2003; Salbu et al., 1994). In the Chernobyl $30 \mathrm{~km}$ zone Konoplev et al. (1993) and Askbrant et al. (1996) reported that $80-90 \%$ of the strontium was associated with fuel particles. Even more than a hundred km away from the Chernobyl NPP, fuel particles constituted a significant part of the strontium contamination (Kuriny et al., 1992). The 'duality' of the fuel particles and condensation aerosols carrying strontium from the Chernobyl accident can be illustrated through the results of modified 'Tessier type' sequential extractions (see Tessier, 1979) carried out on soils contaminated with Chernobyl Sr at various distances from the Chernobyl NPP (Salbu et al., 1994). In the nearest investigated areas (at 50 $\mathrm{km}$ distance), by far the greatest part of the strontium in the soil was in strongly bound forms that could only be extracted with hydrogen peroxide or nitric acid, whereas in areas at greater distances (170-450 $\mathrm{km}$ ), by far the majority of the strontium was in much more easily soluble forms. Parallel tests with stable Sr were employed to rule out effects of the different specific soil types. It should be noted that since ${ }^{89} \mathrm{Sr}$, ${ }^{90} \mathrm{Sr}$ and ${ }^{90} \mathrm{Y}$ cannot be determined in straightforward gamma spectrometry, but usually require chemical separation of strontium from other radionuclides in the sample, prior to radiometric analysis, they are 'inconvenient' to study for instance in aerosol samples, where they have to a large extent been ignored both after the Chernobyl and the Fukushima accident (Steinhauser, 2014). However, even in the Fukushima case ${ }^{90} \mathrm{Sr}$ contamination has been measured in the vicinity of the Fukushima NPP (Steinhauser et al., 2014) at reported levels of about $1 \mathrm{kBq} / \mathrm{kg}$ soil (note: as this figure was published without indications of the depth/dimensions of the soil sample taken, it only qualitatively indicates the presence of strontium).

Ruthenium is special in that it has a very high elemental boiling point $\left(2700^{\circ} \mathrm{C}\right)$, which would in practically any conceivable incident scenario prevent it from being volatilised and depleted from fuel material. However, if oxygen is present, it can be oxidised to its tetraoxide form, which is highly volatile (Kashparov et al., 1996; Hunt et al., 1994). From the Chernobyl accident, ruthenium radionuclides were in great amounts dispersed as condensation particles. This would be expected to have occurred in connection with the fire that followed the explosion. In fact, more ruthenium than caesium was released in connection with the Chernobyl accident (IAEA, 1991), and this had a considerable impact on doses over the first few years $\left({ }^{106} \mathrm{Ru}\right.$ has a half-life of very close to 1 year). The explanation offered by Le Petit et al. (2014) as to why only small amounts of ruthenium were measured in the environment after the Fukushima accident was that it seems that the fuel remained under water in the spent fuel pools (thus no air ingress). Instead the low volatility of ruthenium is reported to be consistent with overheating and fuel melting of reactor cores. Oxidation could in reality occur in all accident scenarios currently represented in RODOS (Bujan, 2014). However, since this is a critical parameter, and oxidation obviously may not always be expected, it would be useful to run the DSS with different assumptions in this respect, both for training purposes and for early 
prognostic runs, when actual scenario specific processes have not yet been disclosed through measurements. It is well known that ruthenium in irradiated $\mathrm{UO}_{2}$ fuel appears in small metallic alloy precipitations together with other fission product elements such as molybdenum, technetium, rhodium, and palladium (Ver et al., 2007). Such precipitations are in metallographic images seen as generally spherical white inclusions.

It is difficult to predict the physicochemical forms that would arise in any future nuclear power plant accidents, as these would be largely dependent on the exact inventory and accident processes at the NPP. Although for example the international Phebus Fission Product Programme (Gonfiotti and Paci, 2018) shed some new light on possible releases in different NPP accident processes, the results reflect specific conditions and do not provide the range of details needed in operational nuclear preparedness for a specific NPP construction. However, perhaps in the future, results of such investigations could be used together with for example the Rapid Source Term Prediction (RASTEP) system (Knochenhauer, 2013), focusing on estimating the state of the specific NPP at the time of the accident using a Bayesian belief network to provide a probabilistic overview of possible accident states. By estimating the processes at the NPP, also the physicochemical forms of the various potentially released contaminants could be estimated. In a recent publication Havskov Sørensen et al. (2018) comment on the requirements to do this.

\subsubsection{Dry deposition}

It is important to note that the background data for the derived deposition parameter values given in Table 1 may possibly not reflect the full range of possible parametric variation, as they are generally taken from a limited number of actual sets of environmental observations of deposition velocity of elemental iodine and relevant aerosols with different AMADs on different surfaces in connection with the Chernobyl accident, the Fukushima accident and various experimentation (Atkins, 1967; Belot, 1977; Bonka, 1989; Bonka \& Horn, 1980; Chamberlain, 1953; Chamberlain, 1967; Clough, 1975; Collins et al., 2004; Freer-Smith et al., 2003; Garland, 2001; Horn et al., 1988; Jonas, 1984; Jonas \& Vogt, 1982; Kashparov et al., 1999; Lai \& Nazaroff, 2005; Little, 1977; McMahon \& Denison, 1979; Mück et al., 2002; Nicholson, 1989; Nicholson \& Watterson, 1992; Petroff, 2005; Roed, 1985; Roed, 1987; Roed, 1988; Roed, 1990; Schwartz, 1986; Sehmel, 1973; Tschiersch et al., 2009; Vargas et al., 2016; Watterson \& Nicholson, 1996). However, these relations between deposition on different surfaces in the same scenario are obviously associated with comparatively much less variation than would relations between deposition velocities in general to these surfaces.

For example, deposition velocity depends on atmospheric stability. It has been demonstrated that under moderately stable atmospheric conditions (e.g., night time with clear sky), the friction velocity will only be about half of its value under neutral conditions (Jensen, 1981). This in turn means that the eddy diffusion part of the deposition velocity will be reduced to about a quarter (IAEA, 1994).

Also wind velocity can greatly influence deposition velocity. It has been demonstrated (Ahmed, 1979) that between wind velocities of 2 and $14 \mathrm{~m} \mathrm{~s}^{-1}$, the deposition velocity of naturally occurring radioactive aerosols increases by about a factor of 3 , both to smooth (e.g., filter paper) and rough (grass) surfaces. It has also been shown (Freer-Smith et al., 2003; Slinn, 1982) that deposition velocities of ca. $0.8 \mu \mathrm{m}$ particles to trees can increase by a factor of 3-4 between wind velocities of 3-9 $\mathrm{m} \mathrm{s}^{-1}$. Even at moderate wind 
velocities $\left(<5 \mathrm{~m} \mathrm{~s}^{-1}\right)$, the deposition of particles on walls facing the wind direction can be several times higher than that on leeside walls, for particles of sizes between about $10^{-2}$ and $20 \mu \mathrm{m}$ (Freer-Smith et al., 2003). As the particle size increases beyond about $20 \mu \mathrm{m}$, the influence of wind speed on deposition increases markedly, due to the significance of the inertial impaction mechanism (Ahmadi \& Li, 1999). However, such large particles will in any case only remain airborne for short time, due to their large mass, and radionuclides associated with these would thus only contaminate rather small areas, depending on, e.g., the initial plume rise height (Hage, 1961; Ivanov, 2009).

Finally, surface roughness is an important parameter. An indication of this influence can be seen from measurements made in the Roskilde area after the Chernobyl accident. Here deposition velocities to grassed surfaces varied rather widely (Roed, 1990) between 1.8 and $8.8 \mathrm{~m} \mathrm{~s}^{-1}$. However, if the length of the grass is taken into account (by dividing with the grass mass per unit area), the results are consistent within $10 \%$. It should therefore be noted that grassed areas in inhabited environments must be well-defined with respect to roughness (grass length). Differences of up to about a factor of 2 have been recorded (Lai \& Nazaroff, 2005) for deposition velocities of 0.9-9.1 $\mu \mathrm{m}$ particles to vertical sandpaper surfaces, ranging from Sand 60 to Sand 220. As shown in Table 1, dry deposition will vary to roof pavings of different materials having different roughness.

Deposition to coniferous trees and deciduous trees in leaf would according to available literature be similar (Jonas, 1984). However, during the winter period where deciduous trees are leafless, the deposition to these would be very low. According to measurements made after the Chernobyl accident (Roed, 1988), the needles or leaves receive some $98 \%$ of the bulk $0.7 \mu \mathrm{m}$ aerosol deposition on a tree. However, relatively not quite insignificant deposition velocities of trace particles have been reported to bare trees in forests (Höfken et al., 1981) (ca. 10-30 \% of that to the same trees in leaf). This is explained by a higher wind speed in a forest with bare trees, but this effect would not be expected to be relevant for single trees in an inhabited area (Jonas, 1984). Only trees in leaf are thus considered in the table. In the period where they are not in leaf, the deposition to these surfaces may be assumed to be comparatively negligible. Note that in the surface contamination values for trees, shrubs, plants and grass in the tables of this report are given per projected area of ground covered by the vegetation canopy, and then normalised according to the contamination level value on the reference surface.

Unfortunately, no measurements of deposition velocities on surfaces in inhabited areas were reported after the Fukushima accident.

In the ERMIN model deposition on different surfaces in the inhabited environment is dealt with relatively to the deposition to a defined reference surface - in this case a newly shortcut lawn was selected (here a quick measurement the relationship between deposition on the grass and the underlying soil can also give a useful indication of the local extent of dry and wet deposition). In ARGOS and RODOS, the deposition process to the reference surface is dealt with in the applied atmospheric dispersion model tool, and not in ERMIN. ERMIN has been designed on the background of the Chernobyl and Fukushima experience to hold information for elemental iodine gas and for aerosols in four characteristic groups with different size ranges (AMAD less than $2 \mu \mathrm{m}, 2-5 \mu \mathrm{m}, 5-10 \mu \mathrm{m}$ and $10-20 \mu \mathrm{m}$ ). The initial surface contamination relations within each group are all assumed to be representable by normal distributions. Typically reported values of the dry deposition velocity in units of $10^{-4} \mathrm{~m} / \mathrm{s}$ to the reference surface are for these contaminant groups respectively of the order of for elemental iodine: 20 , for $0-2 \mu \mathrm{m}$ aerosols: 4 , for $2-5 \mu \mathrm{m}$ aerosols: 7 , for $5-10$ 
$\mu \mathrm{m}$ aerosols: 30 and for 10-20 $\mu \mathrm{m}$ aerosols: 130 (see references above), but case-specific factorial dependencies and thus overall uncertainties are large as explained above.

Table 1. Values for deposition to different surfaces relative to that on the grassed reference surface, for situations when dry deposition dominates. The term 'sd' denotes one standard deviation. All distributions are assumed to be normal. Values are given for elemental iodine gas and for particles with AMAD $<2 \mu \mathrm{m}$, 2-5 $\mu \mathrm{m}, 5-10 \mu \mathrm{m}$ and $10-20 \mu \mathrm{m}$.

\begin{tabular}{|c|c|c|c|c|c|c|c|c|c|c|}
\hline \multirow[t]{2}{*}{ Surface } & \multicolumn{2}{|c|}{$\begin{array}{c}\text { Elemental } \\
\text { iodine }\end{array}$} & \multicolumn{2}{|c|}{$\begin{array}{l}\text { AMAD } \\
<2 \mu \mathrm{m}\end{array}$} & \multicolumn{2}{|c|}{$\begin{array}{l}\text { AMAD } \\
2-5 \mu \mathrm{m}\end{array}$} & \multicolumn{2}{|c|}{$\begin{array}{l}\text { AMAD } \\
5-10 \mu \mathrm{m}\end{array}$} & \multicolumn{2}{|c|}{$\begin{array}{c}\text { AMAD } \\
10-20 \mu \mathrm{m}\end{array}$} \\
\hline & Mean & sd & Mean & sd & Mean & sd & Mean & sd & Mean & sd \\
\hline Short grass* & 1.0 & Ref. surf. & 1.0 & Ref. surf. & 1.0 & Ref. surf. & 1.0 & Ref. surf. & 1.0 & Ref. surf \\
\hline Bare soil & 0.6 & 0.4 & 0.3 & 0.15 & 0.3 & 0.15 & 0.17 & 0.10 & 0.23 & 0.12 \\
\hline Soil and short grass* & 1.0 & - & 1.0 & - & 1.0 & - & 1.0 & - & 1.0 & - \\
\hline Small plants* & 0.8 & 0.5 & 1.4 & 0.7 & 1.6 & 0.8 & 1.0 & 0.5 & 1.2 & 0.7 \\
\hline Trees and shrubs* & 0.4 & 0.25 & 2.5 & 1.2 & 4.3 & 2.5 & 1.7 & 1.2 & 1.5 & 1.1 \\
\hline Paved area & 0.2 & 0.1 & 0.25 & 0.15 & 0.75 & 0.35 & 0.3 & 0.15 & 0.3 & 0.25 \\
\hline Clay tile roof & 1.5 & 0.3 & 0.8 & 0.1 & 3.0 & 0.8 & 1.9 & 0.5 & 1.5 & 0.4 \\
\hline Concrete tile roof & 1.8 & 0.4 & 1.0 & 0.2 & 4.0 & 1.0 & 2.2 & 0.6 & 1.6 & 0.4 \\
\hline Fibre cement roof & 1.6 & 0.3 & 0.9 & 0.1 & 3.6 & 0.9 & 2.1 & 0.5 & 1.6 & 0.4 \\
\hline $\begin{array}{l}\text { Silicon covered fibre } \\
\text { cement roof }\end{array}$ & 1.0 & 0.2 & 0.7 & 0.1 & 2.5 & 0.6 & 1.7 & 0.4 & 1.4 & 0.4 \\
\hline Glass roof & 0.5 & 0.1 & 0.4 & 0.1 & 1.4 & 0.4 & 1.5 & 0.4 & 1.3 & 0.3 \\
\hline Smooth metal roof & 0.7 & 0.1 & 0.5 & 0.1 & 1.6 & 0.4 & 1.6 & 0.4 & 1.3 & 0.3 \\
\hline External walls & 0.15 & 0.1 & 0.03 & 0.02 & 0.07 & 0.04 & 0.1 & 0.07 & 0.05 & 0.03 \\
\hline
\end{tabular}

*Values given per area of ground covered by the vegetation.

\subsubsection{Wet deposition}

Table 2 shows estimates of the relative wet depositions to the different surfaces for each type of contaminant (again, the modelling of deposition to the shortcut grassed reference surface is, in ARGOS and RODOS, included in the atmospheric dispersion estimation tool). Also shown in this table is the fraction of the deposition to each surface which is practically instantaneously carried away, e.g., to sewers, with runoff water. Even during periods of strong rain, deposition to surfaces occurs through a combination of wet and dry deposition. However, unless the rain is extremely light or brief during such a phase or only leads to slight contaminant scavenging from the plume (not assumed for this deposition weather category), wet deposition will clearly be the dominant contamination process. Dry deposition contributions can thus be assumed to be negligible for the deposition weather category covered in this section. The initial run-off of contaminants in rainwater during the wet deposition process may depend on the surface roughness/permeability/porosity and rainfall intensity immediately before as well as during the wet deposition episode (Bonka \& Horn, 1980; Karlberg, 1986; Sartor et al., 1974; Shaw et al., 2006). Further, the surface material type has been reported to be able to influence run-off through pH (Göbel et al., 2007).

On roofs compared with the grassed reference surface, the rain intensity incident per unit roof area will be less by $\cos (\mathrm{v})$, where $\mathrm{v}$ is the roof angle. It is assumed that common roofs have a slope of between 0 and 45 degrees. The initial retention after wet deposition of a range of Chernobyl contaminants $\left({ }^{134} \mathrm{Cs},{ }^{137} \mathrm{Cs},{ }^{103} \mathrm{Ru}\right.$, ${ }^{106} \mathrm{Ru},{ }^{140} \mathrm{La}$ and ${ }^{140} \mathrm{Ba}$ ) with different physicochemical characteristics was recorded on different types of roof 
pavements with different slopes in Denmark following the Chernobyl accident (Roed, 1987). Caesium, which is in cationic form retained selectively and strongly in many building materials (Andersson, 2009), seems to be somewhat more efficiently retained on the roof than other contaminants. In general, the initial retention after the deposition process varies greatly with the roof material. For a range of materials and radionuclides, in the region of one-sixth to half of the contaminants were instantaneously removed with the run-off rain water. The exception from this was silicon-treated very smooth roofs with extremely low open porosity, where the run-off percentage was as high as $70-80 \%$. The main cause of variation here was by far the roof material and not the roof angle nor the radionuclide. Corresponding measurements made in Germany and the United Kingdom of wet-deposited Chernobyl radiocaesium on clay and concrete roofs showed similar values (Roed \& Jacob, 1990; Sandalls \& Gaudern, 1986). It should be noted that contaminant run-off in rainwater is likely to be more dominant when the roof pores are already filled by rain than when contaminated rain falls on a dry roof (Roed, 1987). Ritchie (1976) found that run-off from artificial surfaces in an urban area (e.g., roofs) would be virtually $100 \%$ for all rainfall above an initially accumulated $3 \mathrm{~mm}$, and if there has been rain within the previous hour the run-off will occur sooner.

Wet contamination levels on walls would in general be expected to be low, but associated with some variation according to factors such as the wind speed and direction during the contaminating process. In the Gävle area, which was wet-contaminated by the Chernobyl accident, a caesium contamination level on walls of slightly less than $1 \%$ relative to the reference surface was recorded in 1988 (Andersson, 1991). Figures reported by Roed \& Jacob (1990) for the same location were by mistake somewhat higher (up to $3 \%)$, as the contamination estimate for the grassed reference surface originated from a direct measurement, not allowing for contaminant penetration.

Only a couple of weeks after the Chernobyl accident, the initial retention on street pavings of wet deposited contaminants was measured in Sweden (Karlberg, 1986; Karlberg, 1992). It was found that at this point, some $40-70 \%$ of the radiocaesium incident on asphalt and differently textured concrete street pavings had been removed, most likely to a very high extent already during the deposition phase, with the run-off water. Somewhat less had been removed from rough concrete paving slabs. Similar figures were found for the more refractory ${ }^{140} \mathrm{Ba}$ and ${ }^{110 \mathrm{~m}} \mathrm{Ag}$ that were according to Rulik et al. (1989) associated with particles with a size of several microns after Chernobyl, indicating that particle size within the range of interest has little influence on the fraction of contamination lost with run-off water. Also Jacob et al. (1990) reported results of measurements of wet deposition of Chernobyl caesium, on different urban pavings in Germany. After 32 days, $28-32 \%$ of the caesium remained on concrete pavings, and $36 \%$ in an asphalted parking lot. A measurement after 40 days in an asphalted square showed $32 \%$ retention. In a different area, the retention on concrete pavings after 160 days was found to be $33 \%$. By extrapolation from the curves obtained for the different locations, it could be estimated that the initial retention was in the German region of $35-50 \%$.

Experience with non-radioactive pollutants demonstrates that rain often leaves comparatively little contamination on vegetation (Gravenhorst \& Höfken, 1982). The deposition before run-off for trees is interpreted as the deposition per unit ground area covered by the tree. Contaminants in the precipitation above the tree canopy will either be intercepted by the tree, lost by throughfall (falling directly through leaf gaps or dripping from leaves, needles, twigs and branches), or lost by stemflow (flow down stems or boles). It has been reported (Alexander \& Cresser, 1994) that both for birch trees (Betula pubescens) and pine 
trees (Pinus sylvestris L.) the throughfall precipitation fraction is some $80 \%$ of the incident precipitation. This is an average figure for a two-year study in the English Midlands, in an area with an annual precipitation of $930 \mathrm{~mm}$. The interception was greatest for the pine tree during summer. This is in agreement with findings of other workers of $80-90 \%$ throughfall and 2-5\% stemflow (Carlyle-Moses, 2004; Kryshev, 1996; Neal et al., 1993; Pryor \& Barthelmie, 2005). However, contaminants do not follow the water fractions evenly. Ronneau et al. (1987) reported that for Belgian spruce contaminated by a $7.4 \mathrm{~mm}$ rainfall episode after the Chernobyl accident significantly less ruthenium and lanthanum than caesium was intercepted. The explanation offered was biological absorption, e.g., by caesium exchange with potassium. It is also known that the rate of penetration of cations through the cuticle of vegetation is inversely related to the radius of the ion, and thus strongly favours caesium (Carini \& Bengtsson, 2001). Similar figures have been reported by other workers for caesium on spruce, whereas deciduous trees have somewhat lower caesium interception (Schell et al., 1996). Schimmack et al. (1991) have reported a caesium interception fraction of $20 \%$ for beech trees. Deciduous trees would in winter conditions be expected to intercept considerably less than indicated by the numbers in Table 2. A rain interception fraction for a leafless pear tree has been reported, which was about half of that of an evergreen oak (Xiao et al., 2000). The same workers stress that interception fractions vary significantly dependent on factors like the structure of the tree and amount of rainfall.

Small plants would in general in the context interception be expected to be well represented by agricultural crops, due to sizes, shapes and textures. It has been reported that interception fractions will depend on the amount of rainfall, and plant type, as well as the stage of plant development (Müller \& Pröhl, 1993). It would seem that a likely interception range relevant to urban small plants would be $10-30 \%$ for most radionuclides (IAEA, 1994; Schell et al., 1996). This would correspond to assuming a leaf area index value of about 5; retention coefficient of 0.2-0.3 mm, and rainfall of 4-10 mm (Müller \& Pröhl, 1993). The leaf area index is the total one-sided leaf canopy area per projected area ground covered by the plant.

For relatively short urban grass, the leaf area index would be of the order of 1-3 (Kammann et al., 2005; Müller \& Pröhl, 1993; Rodriguez et al., 1999), and the retention coefficient would be $0.2 \mathrm{~mm}$ for most radionuclides (Müller \& Pröhl, 1993). With the same assumptions as for small plants regarding rainfall, this would give the retention/run-off expressed by the values in Table 2 (Müller \& Pröhl, 1993). 
Table 2. Values for initial deposition to different surfaces relative to that on the grassed reference surface, for situations when wet deposition dominates. The term 'sd' denotes one standard deviation. Also given are the fractions of the contaminants that immediately run off the surface with rain water during the deposition process.

\begin{tabular}{|c|c|c|c|c|c|c|c|c|c|c|c|c|}
\hline \multirow[t]{3}{*}{ Surface } & \multicolumn{2}{|c|}{$\begin{array}{c}\text { Elemental } \\
\text { iodine }\end{array}$} & \multicolumn{2}{|c|}{$\begin{array}{l}\text { Cationic } \\
\text { caesium }\end{array}$} & \multicolumn{2}{|c|}{$\begin{array}{c}\text { Other } \\
\text { contaminants }\end{array}$} & \multicolumn{2}{|c|}{$\begin{array}{l}\text { Elemental } \\
\text { iodine }\end{array}$} & \multicolumn{2}{|c|}{$\begin{array}{l}\text { Cationic } \\
\text { caesium }\end{array}$} & \multicolumn{2}{|c|}{$\begin{array}{c}\text { Other } \\
\text { contaminants }\end{array}$} \\
\hline & \multicolumn{2}{|c|}{ Rel. deposition } & \multicolumn{2}{|c|}{ Rel. deposition } & \multicolumn{2}{|c|}{ Rel. deposition } & \multicolumn{2}{|c|}{ Runoff fraction } & \multicolumn{2}{|c|}{ Runoff fraction } & \multicolumn{2}{|c|}{ Runoff fraction } \\
\hline & Mean & sd & Mean & $\mathrm{sd}$ & Mean & $\mathrm{sd}$ & Mean & $\mathrm{sd}$ & Mean & sd & Mean & $\mathrm{sd}$ \\
\hline Short grass* & 1 & - & 1 & - & 1 & - & 0.9 & 0.1 & 0.8 & 0.1 & 1 & 0.2 \\
\hline Bare soil & 1 & - & 1 & - & 1 & - & 0 & - & 0 & - & 0 & - \\
\hline Soil and short grass* & 1 & $\begin{array}{l}\text { Ref. } \\
\text { surf. }\end{array}$ & 1 & $\begin{array}{l}\text { Ref. } \\
\text { surf. }\end{array}$ & 1 & $\begin{array}{l}\text { Ref. } \\
\text { surf. }\end{array}$ & 0 & - & 0 & - & 0 & - \\
\hline Small plants* & 1 & - & 1 & - & 1 & - & 0.99 & 0.01 & 0.7 & 0.2 & 0.8 & 0.2 \\
\hline Trees and shrubs* & 1 & - & 1 & - & 1 & - & 0.99 & 0.01 & 0.5 & 0.3 & 0.8 & 0.2 \\
\hline Paved area & 1 & - & 1 & - & 1 & - & 0.97 & 0.03 & 0.55 & 0.15 & 0.55 & 0.15 \\
\hline Clay tile roof & 0.8 & 0.2 & 0.8 & 0.2 & 0.8 & 0.2 & 0.99 & 0.01 & 0.3 & 0.04 & 0.35 & 0.05 \\
\hline Concrete tile roof & 0.8 & 0.2 & 0.8 & 0.2 & 0.8 & 0.2 & 0.99 & 0.01 & 0.4 & 0.05 & 0.45 & 0.06 \\
\hline Fibre cement roof & 0.8 & 0.2 & 0.8 & 0.2 & 0.8 & 0.2 & 0.99 & 0.01 & 0.15 & 0.02 & 0.18 & 0.02 \\
\hline $\begin{array}{l}\text { Silicon covered fibre } \\
\text { cement roof }\end{array}$ & 0.8 & 0.2 & 0.8 & 0.2 & 0.8 & 0.2 & 0.99 & 0.01 & 0.8 & 0.1 & 0.9 & 0.1 \\
\hline Glass roof & 0.8 & 0.2 & 0.8 & 0.2 & 0.8 & 0.2 & 0.99 & 0.01 & 0.95 & 0.05 & 0.95 & 0.05 \\
\hline Smooth metal roof & 0.8 & 0.2 & 0.8 & 0.2 & 0.8 & 0.2 & 0.99 & 0.01 & 0.9 & 0.07 & 0.9 & 0.07 \\
\hline External walls & 0.01 & 0.01 & 0.01 & 0.01 & 0.01 & 0.01 & 0 & - & 0 & - & 0 & - \\
\hline
\end{tabular}

*Values given per area of ground covered by the vegetation.

\subsubsection{Equal amounts of wet and dry deposition}

ERMIN also operates with a case, where contributions of wet and dry deposition are of approximately the same magnitude. Since precipitation is very effective in washing out contaminants from a plume, this case would be associated with very little rain, and comparatively rather little contamination would be removed with the run-off water during the deposition process. This is for instance clear from investigations in areas in Russia, which received some rain as the contaminated plume carrying primarily caesium condensation particles passed from Chernobyl. Here, dry deposition rarely contributed more than one or two percent to the total deposition on the reference surface (Andersson et al., 2002). It would thus in most cases only take very little precipitation during the plume passage to make wet deposition the dominant mechanism of contamination. Table 3 shows estimates of the relative depositions to the different surfaces for each type of contaminant assuming that half of the deposition is wet and the other dry (simple averaging with parameters described above). Also the fractions of the deposit removed by run-off water during the contamination process are estimated on the basis of the same literature as used for the wet deposition mode, but assuming very little water. The rainfall rate is here assumed to be well below $1 \mathrm{~mm}$ per hour. Experimental and theoretical work has demonstrated that at low precipitation values $(<\mathrm{ca} .0 .5 \mathrm{~mm})$, the majority of a contamination deposited in solution on a grassed area will remain on the grass (Bonka \& Horn, 1980).

Other modes of deposition (e.g., deposition in fog, deposition in snow and deposition to snow covered landscape) still remain to be implemented in the ERMIN model, although some parametric reviews have been conducted. 
Table 3. Values for initial deposition of different contaminant groups to different surfaces relative to that on the grassed reference surface, for situations when wet and dry deposition are about equal in magnitude. The term 'sd' denotes one standard deviation. Also given are the fractions of the contaminants that immediately run off the surface with rain water during the deposition process.

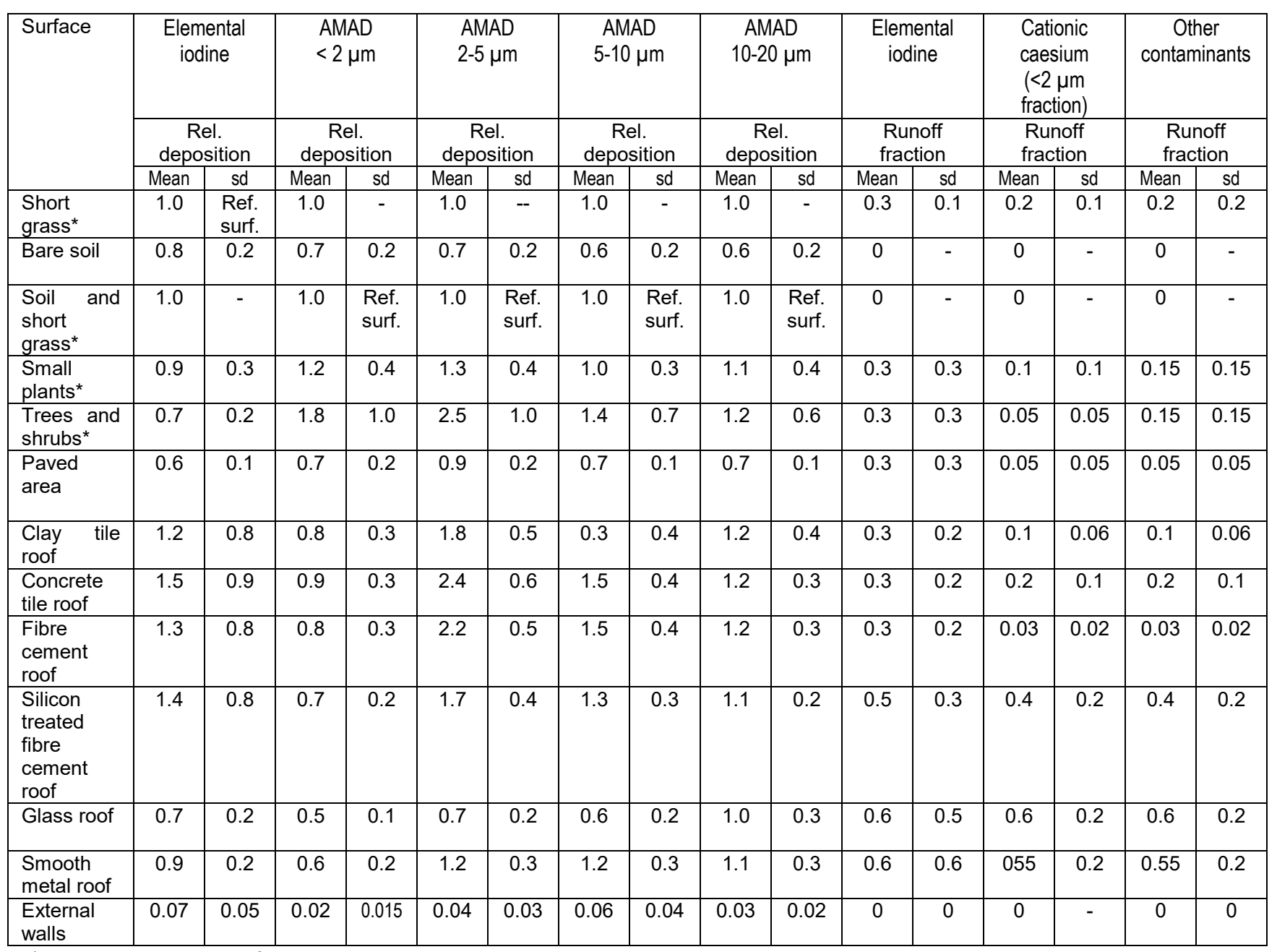

*Values given per area of ground covered by the vegetation.

\subsection{Dose rate conversion factors for different locations in inhabited areas}

Currently, the ERMIN model largely relies on a series of Monte Carlo computed dose rate conversion factors, which date more than 30 years back (Meckbach et al., 1988). The dose rate conversion factors were calculated for essentially four different types of inhabited environment, ranging from detached suburban houses of light construction to urban centres with 4-storey brick buildings with relatively thick walls. Since then, only a few specialised environments have been added to the ERMIN dose rate conversion factor database, involving industrial buildings and supermarkets (Kis et al., 2004). However, there are still a number of typical European inhabited environments that would not be well described by any of the data currently in the database. For instance, city centres contain many tall buildings of modern construction (e.g., with much 
glass). Therefore, dose conversion factors for a modern tall urban glass front construction house were calculated and will be published separately (Hinrichsen \& Andersson, 2018).

The applicability of the Monte Carlo calculation code MCNP6 (Goorley et al., 2012) in calculating shieldingfactors for inhabited environments was validated through comparison with in situ measurements in the inhabited environment being modelled (Hinrichsen et al., 2018). Generally, a comparison between computed and determined dose rate factors (or shielding factors) for different target points for a contamination of ${ }^{134} \mathrm{Cs}$ and ${ }^{137} \mathrm{Cs}$ on different surfaces gave an average ratio of $1.02 \pm 0.05$. Among other processes the MCNP6 code accounts for photon creation and loss through bremsstrahlung, $p$-annihilation, fluorescence, Compton scattering, pair production and photon capture (Goorley et al., 2012). The code allows the definition of complex three-dimensional geometries through a combinatorial geometry technique. The regions in space were constructed by logical combination (union, intersection, difference) of elementary geometric bodies and surfaces.

A new re-calculation has been made with the MCNP6 code of one of the scenarios for which dose rate conversion factors were reported more than 30 years earlier by Meckbach et al. (1988) on the basis of Monte Carlo modelling using the code SAM-CE. The house type and the surfaces and neighbouring buildings (see Figure 1) were modelled based on the data published by Meckbach et al (1988), who also provided, e.g., highly detailed descriptions of the assumed construction materials with dimensions, material specifications and densities. Atomic composition data of the different materials were added from a compilation by Pacific Northwest National Laboratory (McConn et al., 2011). The MCNP6 calculations were carried out using the cross section data set (ENDF/B-VII.0; Chadwick et al., 2006) that had been validated in comparison with in situ measurements for a different housing environment as described above. The source and detector regions were defined according to the data given by Meckbach et al. (1988). The number and energies of any radiation passing through the detector regions were scored and by using conversion coefficients (ICRP, 2010) transferred to kerma free-in-air at the end of the calculation.
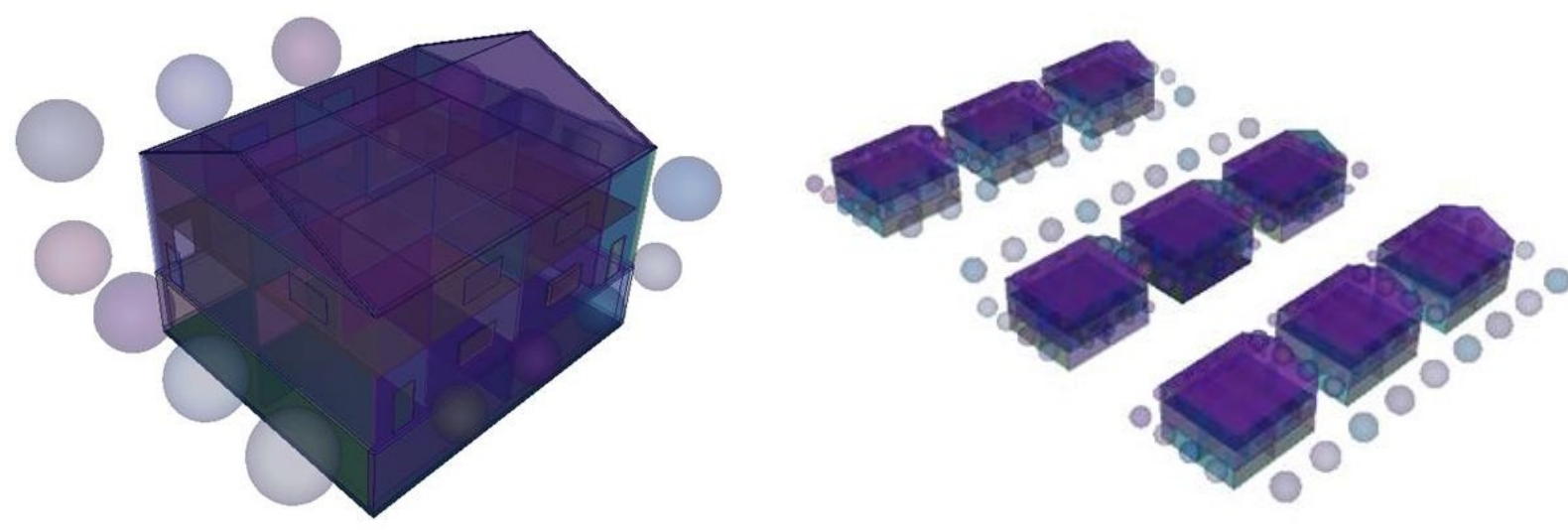

Figure 1. Birds-eye view of the semidetached house without (left) and with (right) neighbouring buildings. The spheres indicate the position of the trees. 
The calculated air kerma values per photon emitted per unit source area were compared to those published at GSF (Meckbach et al., 1988). The ratios of the two data were calculated for different source and detector areas and averaged over three different photon energies $-0.3 \mathrm{MeV}, 0.662 \mathrm{MeV}$ and $3.0 \mathrm{MeV}$ (Table 4). The new calculations only comprise indoor detection positions, as the publications of Meckbach did not disclose the positions assumed for detection in outdoor locations. Note that Meckbach only calculated the contribution to kerma from contamination on trees for the scenario with neighbouring buildings, and thus for comparison the new calculations were made in accordance with this.

Table 4. Ratios of newly calculated air kerma rate conversion factors divided by those previously reported by Meckbach et al. for the same scenario. Figures are given according to source and detection area.

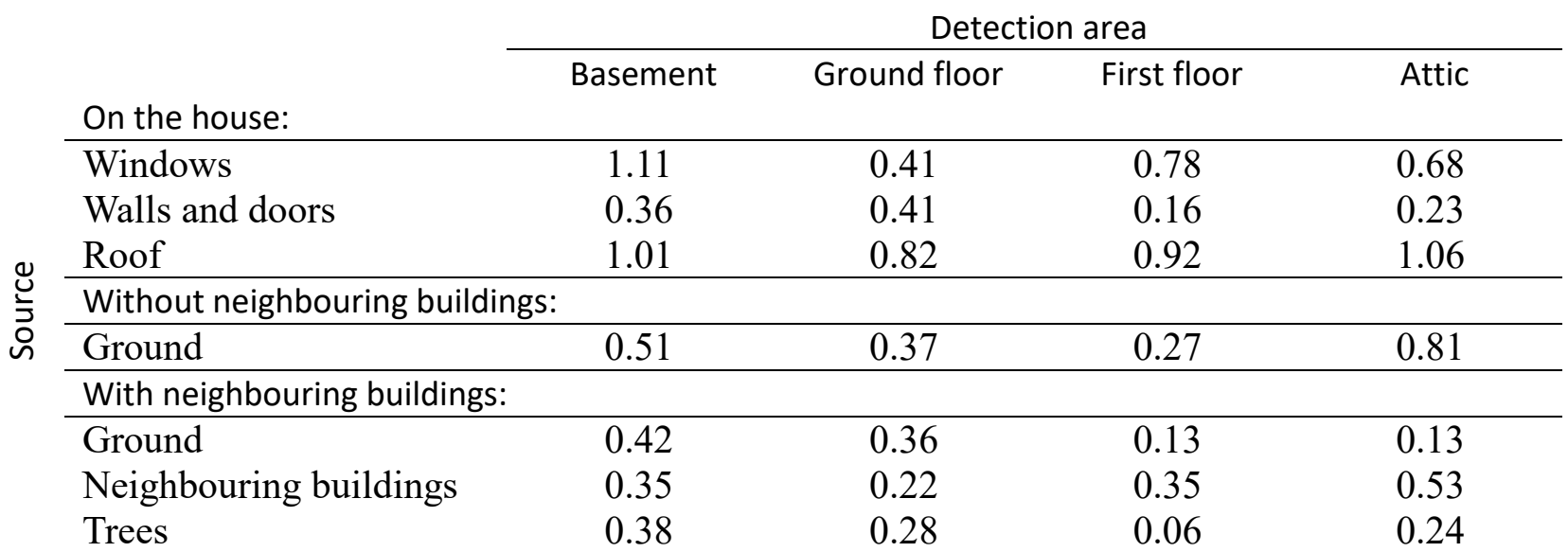

Naturally, part of the difference may be attributable to differences in assumptions regarding atomic compositions of materials, which were not specified in the old publication. However, the rather substantial differences between the calculations for particularly walls and doors show that something more fundamental may be at play, possibly due to the old and perhaps incorrect cross-section libraries that were used with the SAM-CE code. The wall material in this case provides better shielding against radiation than does the roof, and comparatively smaller radiation tallies would thus be scored, and longer computing time required for a good result. However, the code provides ten statistical tests that are performed on each defined detector region. Those tests are a valuable tool to ascertain the statistical quality of the respective results.

Also estimates of contributions to the air kerma from radiation from neighbouring areas (where comparatively small radiation tallies would also be expected) are generally not in good agreement. The results of the new calculations of kerma rate conversion factors in the format applied by Meckbach et al. (1988) and used in the ERMIN data libraries are reported in Tables 5-7 for the photon energies $0.3 \mathrm{MeV}, 0.662$ $\mathrm{MeV}$ and $3.0 \mathrm{MeV}$. 
Table 5. Contribution of the various deposition areas to the kerma at several locations inside a semi-detached house for a source energy of $0.3 \mathrm{MeV}$ in pGy per $y \mathrm{~mm}^{-2}$.

\begin{tabular}{lcccc} 
& \multicolumn{4}{c}{ Detection area } \\
\cline { 2 - 5 } & Basement & Ground floor & First floor & Attic \\
On the house: & & & 6.2 & 1.5 \\
\hline Windows & 0.026 & 2.8 & 1.4 & 1.2 \\
Walls and doors & 0.008 & 4.0 & 24.0 & 84.0 \\
\hline \multirow{5}{*}{\begin{tabular}{l} 
Roof \\
\cline { 2 - 5 }
\end{tabular}} & 0.116 & 7.3 & 10.4 & 29.8 \\
\hline Without neighbouring buildings: & 0.013 & 13.6 & 2.6 & 3.1 \\
\hline Ground & & & 1.9 & 3.9 \\
With neighbouring buildings: & 0.004 & 8.8 & 0.3 & 0.7
\end{tabular}

Table 6. Contribution of the various deposition areas to the kerma at several locations inside a semi-detached house for a source energy of $0.662 \mathrm{MeV}$ in pGy per $8 \mathrm{~mm}^{-2}$.

\begin{tabular}{|c|c|c|c|c|}
\hline \multirow{3}{*}{ On the house: } & \multicolumn{4}{|c|}{ Detection area } \\
\hline & Basement & Ground floor & First floor & Attic \\
\hline & & & & \\
\hline Windows & 0.159 & 6.2 & 20.5 & 4.0 \\
\hline Walls and doors & 0.054 & 7.9 & 3.0 & 3.5 \\
\hline Roof & 0.753 & 17.5 & 57.5 & 198.8 \\
\hline \multicolumn{5}{|c|}{ Without neighbouring buildings: } \\
\hline Ground & 0.060 & 31.0 & 19.4 & 73.1 \\
\hline \multicolumn{5}{|c|}{ With neighbouring buildings: } \\
\hline Ground & 0.020 & 18.9 & 5.3 & 7.7 \\
\hline Neighbouring buildings & 0.007 & 2.3 & 4.2 & 12.1 \\
\hline Trees & 0.012 & 3.2 & 0.5 & 1.9 \\
\hline
\end{tabular}

Table 7. Contribution of the various deposition areas to the kerma at several locations inside a semi-detached house for a source energy of 3.0 $\mathrm{MeV}$ in pGy per $y \mathrm{~mm}^{-2}$.

\begin{tabular}{|c|c|c|c|c|c|}
\hline \multirow{2}{*}{\multicolumn{2}{|c|}{ On the house: }} & \multicolumn{4}{|c|}{ Detection area } \\
\hline & & Basement & Ground floor & First floor & Attic \\
\hline \multirow{9}{*}{ 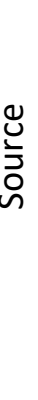 } & Windows & 2.37 & 20.9 & 66.2 & 14 \\
\hline & Walls and doors & 1.10 & 23.1 & 11.0 & 19 \\
\hline & Roof & 9.79 & 69.3 & 218.3 & 722 \\
\hline & Without neighbouring buildings: & & & & \\
\hline & Ground & 0.95 & 108.2 & 46.4 & 416 \\
\hline & With neighbouring buildings: & & & & \\
\hline & Ground & 0.71 & 59.8 & 16.7 & 31 \\
\hline & Neighbouring buildings & 0.15 & 7.9 & 14.5 & 66 \\
\hline & Trees & 0.31 & 11.2 & 1.2 & 9 \\
\hline
\end{tabular}


As the contamination migrates downward in permeable surfaces (soil), the soil above it will shield against the radiation it emits, but in the calculations behind the kerma factors in the above tables, it is assumed that all contamination is on the very surface. The factors thus need to be modified according to contamination penetration depth in the soil. As shown in part 2 of the paper, ERMIN can dynamically calculate the contamination level at different soil depths. A series of pre-calculated modification factors are used to take into account the influence on kerma rate of contaminant penetration at different depths in the soil (Charnock, 2018; Andersson et al., 2008).

\section{Conclusions}

The latest developments for the inhabited areas dose estimation model, ERMIN, which is integrated in the European decision support systems ARGOS and RODOS, are described with respect to two important parameters: the relative contamination level on different surfaces in the inhabited environment and the conversion factor from contamination level to dose rate.

An overview is given of primary contaminants with different physicochemical forms produced in the Chernobyl and Fukushima accidents. It should be noted that future accidents would be likely to have different features and might lead to different types of contaminants. Nevertheless, the lessons from these two major accidents are of great importance. On the basis of available knowledge, the relative deposition of various groups of possible contaminants on the different surfaces in the inhabited environment is estimated. This is an essential requirement in predicting initial dose rates to inhabitants from different contaminated surfaces in representative housing environments. The tables in this paper show that the relative distribution of contaminants on different surfaces can vary considerably according to the physicochemical form (notably elemental iodine gas fraction, aerosol sizes) of the contaminants. Although rough estimates of the expected variation in these parameters are given, it should be noted that ARGOS and RODOS currently do not have inherent options for full visualisation of the implications of uncertainty/variation of such parameters.

The other requirement in predicting initial dose rates in different environmental positions is reliable dose rate conversion factors for different types of inhabited areas. The MCNP6 Monte Carlo radiation transport estimation system, which was recently experimentally validated for dose rate estimation in inhabited areas, was used to recalculate the ca. 30 year-old dose rate (kerma rate in air) conversion factor estimates (made with the Monte Carlo code SAM-CE) for one of the standard inhabited environments integrated in the European decision support systems. The new dose rate factors differed significantly from the old ones, particularly when the radiation passed through substantial masses like outer house walls. The number of tallies seems to have been adequate in both cases (judged from code statistics), and thus not the problem. The explanation might possibly lie in the programming (where MCNP is probably the most widely used and validated of all such codes), and could also reflect differences in cross-section data libraries or unreported case-specific assumptions. The new dose rate conversion factors are reported for use in the decision support systems.

The parameter requirements in predicting future time-integrated doses on this background are dealt with in the second part of the paper. 
Acknowledgments

The authors would like to thank Dr. Thomas W. Charnock at Public Health England for valuable advice in drafting the paper.

Part of the research leading to these results was carried out in the CONFIDENCE project, which is part of the CONCERT project. This project has received funding from the Euratom research and training programme 20142018 under grant agreement No 662287.

An other part of the research leading to these results has received funding from the European Atomic Energy Community Seventh Framework Programme FP7/2012-2013 under grant agreement 323287.

\section{Disclaimer}

This publication reflects only the author's view. Responsibility for the information and views expressed therein lies entirely with the authors. The European Commission is not responsible for any use that may be made of the information it contains.

\section{References:}

Adachi, K., Kajino, M., Zaizen, Y. \& Igarashi, Y., 2013. Emission of spherical caesium-bearing particles from an early stage of the Fukushima accident, Scientific reports, 3:2554, DOI: 10.1038/srep02554.

Ahmadi, G. \& Li, A., 1999. Computer simulation of particle transport and deposition near a small isolated building, Journal of Wind Engineering and Industrial Aerodynamics 84, pp. 23-46.

Ahmed, A.-R. A.-A.,1979. Untersuchungen zur Aerosoldeposition an Oberflächen, Doktor Dissertation, JustusLiebig-Universität Giessen (in German).

Alexander, C. E., Cresser, M. S., 1995. An assessment of the possible impact of expansion of native woodland cover on the chemistry of Scottish freshwaters. Forest Ecology and Management 73, 1-27.

Andersson, K.G., 1989. TACTUS: A Code for Simulation of the Flow of Caesium-137 in Urban Surroundings, in proceedings of the Symposium on Recovery Operations in the Event of a Nuclear Accident or Radiological Emergency, IAEA-SM-316/48, International Atomic Energy Agency, Vienna, Austria, ISBN 92-0-020290-x, pp. 217-228.

Andersson, K.G. 1991. Contamination and decontamination of urban areas, Ph.D. Thesis, Risø National Laboratory.

Andersson, K.G., 2009. Migration of radionuclides on outdoor surfaces, Chapter 5 (pp. 107-146) in K.G. Andersson (editor): Airborne radioactive contamination in inhabited areas, Book Series Radioactivity in the Environment vol. 15 (series editor: M.S. Baxter), Elsevier, ISBN 978-0-08-044989-0, ISSN 1569-4860.

Andersson, K.G., Brown, J., Mortimer, K., Jones, J.A., Charnock, T., Thykier-Nielsen, S., Kaiser, J.C., Proehl, G. \& Nielsen, S.P., 2008. New developments to support decision-making in contaminated inhabited areas 
following incidents involving a release of radioactivity to the environment, J. Environmental Radioactivity, vol. 99, pp. 439-454.

Andersson, K.G., Jones, A. \& Charnock, T., 2009. Estimation of doses in inhabited areas, Chapter 6 (pp. 147185) in K.G. Andersson (editor): Airborne radioactive contamination in inhabited areas, Book Series Radioactivity in the Environment vol. 15 (series editor: M.S. Baxter), Elsevier, ISBN 978-0-08-044989-0, ISSN $1569-4860$.

Andersson, K.G., Roed, J. \& Fogh, C.L., 2002. Weathering of radiocaesium contamination on urban streets, walls and roofs, J. Environmental Radioactivity vol. 62, no.1, pp. 49-60.

Andersson, K.G., Roos, P., Lind, O.C., Salbu, B., Bujan, A., Duranova, T., Ikonomopoulos, A. \& Andronopoulos, S. (2013). Collection and assessment of existingdata on physicochemical properties of emitted radionuclides, and work to categorise accident scenarios accordingly. EU FP7 PREPARE project deliverable report D4.1, PREPARE(WP4)-(13)-01.

ARGOS, 2018. ARGOS CBRN crisis management support system, PDC-ARGOS, Denmark, http://www.pdcargos.com/.

Askbrant, S., Melin, J., Sandalls, J., Rauret, G., Vallejo, R., Hinton, T., Cremers, A., Vandecastelle, C., Lewyckyj, N., Ivanov, Y.A., Firsakova, S.K., Arkhipov, N.P. \& Alexakhin, R.M., 1996. Mobility of radionuclides in undisturbed and cultivated soils in Ukraine, Belarus and Russia six years after the Chernobyl fallout, J. Environ. Radioactivity 31(3), pp. 287-312.

Atkins, D.H.F., Chadwick, R.C. \& Chamberlain, A.C., 1967. Deposition of radioactive methyl iodide to vegetation, Health Physics 13, pp. 91-92.

Belot, Y., 1977. Etude de la caption des pollutants atmospheriques par les végétaux, Report CEA-R-4786, Département de Protection, Centre d'Etudes Nucléaires de Fontenay-aux-Roses.

Bobovnikova, C.I., Virichenko, E.P., Konoplev, A.V., Siverina, A.A. \& Shkuratova, I.G., 1990. Chemical forms of long-term radionuclides and their transformation in the soils of accidental zone of the Chernobyl NPP, Pochvovedenie, 10, 20-29.

Bonka, H., 1989. Measured radioecological parameters after the Chernobyl accident, In: The Radioecology of Natural and Artificial Surfaces (edited by W. Feldt), TUEV Rheinland, Germany.

Bonka, H. \& Horn, M., 1980. Review on the dry and wet deposition of aerosol particles, Lehrgebiet Strahlenschutz in der Kerntechnik, Rhein-Westf. Technische Hochschule, Aachen.

Carini, F. \& Bengtsson, G., 2001. Post-deposition transport of radionuclides in fruit, J. Environmental Radioactivity 52, pp. 215-236.

Carlyle-Moses, D.E., 2004. Throughfall, stemflow, and canopy loss fluxes in a semi-arid Sierra Madre Oriental matorral communuty, Journal of Arid Environments 58(2), pp. 181-202.

Chadwick, M. B., Oblozinsky, P., Herman, M., Greene, N. M., McKnight, R. D., Smith, D. L., Young, P. G., MacFarlane, R. E., Hale, G. M., Frankle, S. C., Kahler, A. C., Kawano, T., Little, R. C., Madland, D. G., Moller, P., Mosteller, R. D., Page, P. R., Talou, P., Trellue, H., White, M. C., Wilson, W. B., Arcilla, R., Dunford, C. L., Mughabghab, S. F., Pritychenko, B., Rochman, D., Sonzogni, A. A., Lubitz, C. R., Trumbull, T. H., Weinman, J. 
P., Brown, D. A., Cullen, D. E., Heinrichs, D. P., McNabb, D. P., Derrien, H., Dunn, M. E., Larson, N. M., Leal, L. C., Carlson, A. D., Block, R. C., Briggs, J. B., Cheng, E. T., Huria, H. C., Zerkle, M. L., Kozier, K. S., Courcelle, A., Pronyaev, V., van der Marck, S. C., 2006. ENDF/B-VII.0: Next generation evaluated nuclear data library for nuclear science and technology. Nuclear Data Sheets 107 (12), 2931-3060.

Chamberlain, A.C., 1953. Aspects of travel and deposition of aerosol and vapour clouds, AERE, HP/ R 1261, Harwell Lab., UK.

Chamberlain, A.C., 1967. Transport of lucopodium spores and other small particles to rough surfaces, Proc. R. Soc. A, vol. 296, pp. 45-70.

Charnock, T.W., Jones, J.A., Singer, L.N., Andersson, K.G., Roed, J., Thykier-Nielsen, S., Mikkelsen, T., Astrup, P., Kaiser, J.C., Müller, H., Pröhl, G., Raskob, W., Hoe, S.C., Jacobsen, L.H., Schou Jensen, L. \& Gering, F., 2009. Calculating the consequences of recovery, a European model for inhabited areas, Radioprotection vol. 44, No.5, pp. 407-412, ISSN 0033-8451.

Charnock, T.W., 2018. Concise description of ERMIN 2.1. The European inhabited dose and decontamination model, Draft report, Centre for Radiation, Chemical and Environmental Hazards, Public Health England, Chilton, Didcot, Oxfordshire, OX11 0RQ, UK.

Clough, W.S., 1975. The deposition of particles on moss and grass surfaces, Atmospheric Environment 9, pp. 1113-1119.

Collins, C.D., Gravett, A.E. \& Bell, J.N.B., 2004. The deposition and translocation of methyl iodide by crops, Health Physics 87(5), pp. 512-516.

Crick, M. J. and Brown, J., 1990. EXPURT - a model for evaluating exposure from radioactive material deposited in the urban environment. Chilton. NRPB-R235.

Dobrovolsky, E., Lyalko, V., 1995. Acidification of soils and radioactive hot particles behavior: A macrokinetic approach. Water Air and Soil Pollution 85, 767-772.

Freer-Smith, P.H., El-Khatib, A.A. and Taylor, G., 2004. Capture of particulate pollution by trees: a comparison of species typical of semi-arid areas (Ficus Nitida and Eucalyptus Globulus) with European and North American species, Water, Air and Soil Pollution 155 (1-4): pp. 173-187.

Garland, J.A., 2001. On the size dependence of particle deposition, Water, Air and Soil Pollution, Focus 1, 323332.

Gonfiotti, B. \& Paci, S., 2018. Stand-alone containment analysis of Phébus FPT tests with ASTEC and MELCOR codes: the FPT-2 test, Helyon 4(3), doi: 10-1016/j.helyon.2018.e00553.

Goorley, T., James, M., Booth, T., Brown, F., Bull, J., Cox, L. J., Durkee, J., Elson, J., Fensin, M., Forster, R. A., Hendricks, J., Hughes, H. G., Johns, R., Kiedrowski, B., Martz, R., Mashnik, S., McKinney, G., Pelowitz, D., Prael, R., Sweezy, J., Waters, L., Wilcox, T., Zukaitis, T., 2012. Initial MCNP6 Release Overview. Nuclear Technology 180, 298-31.

Gravenhorst, G., Höfken, K. D., 1982. Concentration of aerosol constituents above and beneath a beech and a spruce forest canopy, in H. W. Georgii \& J. Pankrath: Deposition of Atmospheric Pollutants, D. Reidel, Dordrecht, the Netherlands. 
Göbel, P., Dierkes, C. \& Coldewey, W.G., 2007. Storm water runoff concentration matrix for urban areas, Journal of Contaminant Hydrology 91, pp. 26-42.

Hage, K. D., 1961. On the dispersion of large particles from a 15-m source in the atmosphere. J. Meteorol. 18, 534-539.

Harper, F.T., Musolino, S.V. \& Wente; W.B., 2007. Realistic radiological dispersal device hazard boundaries and ramifications for early consequence management decisions, Health Physics 93(1), 1-16.

Havskov Sørensen, J., Schönfeldt, F., Sigg, R., Pehrsson, J., Lauritzen, B., Bartnicki, J., Klein, H., Hoe, S.C., Lindgren, J., 2018. Added Value of uncertainty Estimates of SOurce term and Meteorology (AVESOME), NKS report 402, NKS, Roskilde, Denmark, ISBN 978-87-7893-490-1, http://www.nks.org/en/nks_reports/view_document.htm?id=111010214694197.

Hinrichsen, Y. \& Andersson, K. G., 2018. Gamma conversion factors for modern glass buildings in radioactively contaminated areas, paper submitted for publication in J. Radiological Protection.

Hinrichsen, Y., Finck, R., Östlund, K., Rääf, C. \& Andersson, K.G., 2018. Comparison of experimental and calculated shielding factors for modular buildings in a radioactive fallout scenario, J. Environmental Radioactivity 189, pp. 146-155.

Hirose, K., 2016. Fukushima Daiichi Nuclear Plant Accident: Atmospheric and oceanic impacts over the five years, J. Environmental Radioactivity 157, pp. 113-130.

Horn, H.G., Maqua, M. \& Bonka, H., 1988. Nasse und trockene Ablagerung radioaktiver Stoffe auf die Vegetation und den Erdboden. Schriftenreihe Reaktorsicherheit und Strahlenschutz, BMU 199-195, ISSN 07243316 (in German).

Hunt, C.E.L., Cox, D.S. \& Iglesias, F.C., 1994. Fission-product release during accidents - an accident management perspective, Nuclear Engineering and Design 148(2-3), pp. 205-216.

Höfken, K.D., Georgii, H.W. \& Gravenhorst, G., 1981. Untersuchung über die Deposition atmosphärischer Spurenstoffe an Buchen- und Fichtenwald, Berichte des Instituts für Meteorologie und Geophysik der Universität Frankfurt/Main, Nr. 46, Frankfurt.

IAEA, 1991. The International Chernobyl Project, Technical Report, Report by an Advisory Committee, IAEA, International Atomic Energy Agency, Vienna, ISBN 92-0-129191-4.

IAEA, 1994. Modelling the deposition of airborne radionuclides into the urban environment, First report of the VAMP Urban Working Group, IAEA TECDOC 760, International Atomic Energy Agency, Vienna.

IAEA, 2015. The Fukushima Daiichi Accident: Technical Volume 1 - Description and context of the accident, International Atomic Energy Agency, Vienna, ISBN 978-92-0-107015-9. ICRP, 2007. The 2007 recommendations of the International Commission on Radiological Protection, ICRP Publication 103, Annals of the ICRP, Vienna, Austria, ISSN 0146-6453.

ICRP, 2010. Conversion Coefficients for Radiological Protection Quantities for External Radiation Exposures. ICRP Publication 116, Annals of the ICRP 40(2-5), Vienna, Austria, ISSN 0146-6453. 
Ikehara, R., Suetake, M., Komiya, T., Furuki, G., Achiai, A., Yamasaki, S., Bower, W.R., Law, G.T.W., Ohnuki, T., Grambow, B. (2018). Novel method of Quantifying Radioactive Cesium-Rich Microparticles (CsMPs) in the Environment from the Fukushima Daiichi Nuclear Power Plant, Environmental Science and Technology 52(11), pp. 6390-6398.

Ivanov, Y., 2009. Migration of fuel particles of ChNPP fallout and leached radionuclides in soils and soil-toplant system, In: 'Radioactive Particles in the Environment', Proceedings of the NATO Advanced Research Workshop on Hot Particles Released from Different Nuclear Sources, Yalta, Ukraine, 7-10 May 2007, Springer, Dordrecht, The Netherlands, ISBN 978-90-481-2949-2.

Jacob, P., Meckbach, R. \& Müller, H.M., 1987. Reduction of external exposure from deposited Chernobyl activity by run-off, weathering, street cleaning and migration in the soil, Radiation Protection Dosimetry 21(1/3), 51-57.

Jensen, N.O., 1981. A micrometeorlogical perspective on deposition, Health Physics 40(6), pp. 887-891.

Jensen, P. H., Thykier-Nielsen, S., 1989. Shielding factor calculation for plume radiation. Radiation Protection Programme. Progress Report 1988, 1561- 1565.

Jonas, R., 1984. Ablagerung und Bindung von Luftverunreinigungen an Vegetation und anderen atmosphärischen Grenzflächen, Kernforschungsanlage Jülich GmbH, Abteilung Sicherheit und Strahlenschutz, Jül-1949, ISSN 0366-0885.

Jonas, R. \& Vogt, K.J., 1982. Untersuchungen zur Ermittlung der Ablagerungsgeschwindigkeit von Aerosolen auf Vegetation und anderen Probenahmeflächen, Kernforschungsanlage Jülich GmbH, Abteilung Sicherheit und Strahlenschutz, Jül-1780, ISSN 0366-0885.

Jost, D.T., Gäggeler, H.W., Baltensperger, U., Zinder, B. \& Haller, P., 1986. Chernobyl fallout in sizefractionated aerosol, Nature 324, pp. 22-23.

Kammann, C., Grünhage, L., Gruters, U., Janze, S. \& Jäger, H.J., 2005. Response of aboveground grassland biomass and soil moisture to moderate long-term CO2 enrichment, Basic and Applied Ecology 6 (4), pp. 351365.

Kaneyasu, N., Ohashi, H., Suzuki, F., Okuda, T. \& Ikemori, F., 2012. Sulfate aerosol as potential transport medium of radiocesium from the Fukushima nuclear accident, Environmental Science and Technology 46, 57205726.

Karlberg, O., 1986. Avrinning och retention av Chernobyl nedfallet i stadsmiljö - Fält-mätningar med gamma spectrometer (in Swedish), Technical Note (6 pages), Studsvik AB, Nyköping, Sweden.

Karlberg, O., 1992. The environmental behaviour of Chernobyl deposition in a high fallout region of Sweden Measurements and analysis of the urban programme 1986-1989, Studsvik Nuclear, Stockholm, Sweden, Report NS-92/1, ISBN 91-7010-184-1.

Kashparov, V.A., Ivanov, Y.A., Zvarisch, S.I., Protsak, V.P., Khomutinin, Y.V., Kurepin, A.D. \& Pazhukin, E.M., 1996. Formation of hot particles during the Chernobyl nuclear power plant accident, Nuclear Technology 114(2), pp. 246-253. 
Kashparov, V.A., Lundin, S.M., Zvarych, S.I., Yoschenko, V.I., Levchuk, S.E., Khomutinin, Y.V., Maloshtan, I.M. \& Protsak, V.P., 2003. Territory contamination with the radionuclides representing the fuel component of the Chernobyl fallout, Sci. Tot. Environment 317, 105-119.

Kashparov, V.A., Protsak, V.P., Ahamdach, N., Stammose, D., Peres, J.M., Yoschenko, V.I. \& Zvarich, S.I., 2000. Dissolution kinetics of particles of irradiated Chernobyl nuclear fuel: influence of $\mathrm{pH}$ and oxidation state on the release of radionuclides in the contaminated soil of Chernobyl, J. Nucl. Materials 279, 225-233.

Kis, Z., Eged, K., Voigt, G., Meckbach, R., Müller, H., 2004. Modeling an industrial environment: External dose calculations based on Monte Carlo simulations of photon transport, Health Physics, 86, pp. 161-173.

Knochenhauer, M., Hedtjärn Swaling, V., Di Dedda, F., Hansson, F., Sjökvist, S. \& Sunnegård, K., 2013 . Using Bayesian Belief Network (BBN) Modelling for Rapid Source Term Prediction - Final Report. NKS report 293, NKS, Roskilde, Denmark, ISBN 978-87-7893-369-0. http://www.nks.org/en/nks_reports/view_document.htm?id=111010111846390.

Konoplev, A.V., Bulgakov, A.A., Popov, V.E. \& Bobovnikova, T.I., 1993. Behaviour of long-lived Chernobyl radionuclides in a soil-water system, Analyst 117, pp. 1041-1047.

Kryshev, I.I., 1996. Dose reconstruction for the areas of Russia affected by 131I contamination, Radiation Protection Dosimetry 64 (1/2), 93-96.

Kuriny, V.D., Ivanov, Yu. A., Kashparov, V.A., Loshchilov, N.A., Protsak, V.P., Yudin, E.B., Zhurba, M.A., Parshakov, A.E., 1993. Particle-associated Chernobyl fallout in the local and intermediate zones, Ann. Nucl. Energy 20(6), 415-420.

Lai, A.C.K. \& Nazaroff, W.W., 2005. Supermicron particle deposition from turbulent chamber flow onto smooth and rough vertical surfaces, Atmospheric Environment 39, pp. 4893-4900.

Le Petit, G., Douysset, G., Ducros, G., Gross, P., Achim, P., Monfort, M., Raymond, P., Pontillon, Y., Jutier, C., Blanchard, X., Taffary, T. \& Moulin, C., 2014. Analysis of radionuclide releases from the Fukushima Dai-ichi nuclear power plant accident part I, Pure Applied Geophys. 171, 629-644.

Lichtenstein, H., Cohen, M., Steinberg, H., Troubetzkoy, E. \& Beer, M., 1979. The SAM-CE Monte Carlo system for radiation transport and criticality calculations in complex configurations (Revision 7.0). A computer code manual (Mathematical Application Group inc., 3 Westchester Plaza, Elmsfort, NY 10523, USA.

Lin, Y.C., Liu, Y.H., Nievaart, S., Chen, Y.F., Wu, S.W., Chou, W.T., Jiang, S.H., 2011. Simulation of the $\mathrm{Mg}(\mathrm{Ar})$ ionization chamber currents by different Monte Carlo codes in benchmark gamma fields, Nuclear Instruments \& Methods in Physics Research Section A - Accelerators Spectrometers Detectors and Associated Equipment, pp. 559-563.

Lind, O.C., 2006. Characterisation of radioactive particles in the environment using advanced techniques. $\mathrm{PhD}$ thesis. Norwegian University of Life Sciences, pp. 1-191.

Lind, O.C., Salbu, B., Skipperud, L., Janssens, K., Jaroszewicz, J., De Nolf, W., 2009. Solid state speciation and potential bioavailability of depleted uranium particles from Kosovo and Kuwait. Journal of Environmental Radioactivity 100, 301-307. 
Little, P., 1977. Deposition of 2.75, 5.0 and $8.5 \mu \mathrm{m}$ particles to plant and soil surfaces, Environ. Pollution 12, 293-305.

Loschilov, N.A., Kashparov, V.A., Yudin, Ye. B., Protsak, V.P., Zhurba, M.A.\& Parshakov, A.E., 1991. Experimental assessment of radioactive fallout from the Chernobyl accident, Sicurezza e protezione 25-26, 4650.

Mala, H., Rulík, P., Becková, V., Mihalík, J. \& Slezáková, M., 2013. Particle size distribution of radioactive aerosols after the Fukushima and the Chernobyl accidents, J. Environ. Radioactivity 126, 92-98.

McConn Jr, R. J., Gesh, C. J., Pagh, R. T., Rucker, R. A., Williams III, R.G., 2011. Radiation Portal Monitor Project - Compendium of Material Composition Data for Radiation Transport Modeling. Pacific Northwest National Laboratory, PIET-43741-TM-963; PNNL-15870 Rev. 1.

McMahon, T.A. \& Denison, P.J., 1979. Empirical atmospheric deposition parameters - a survey, Atmospheric Environment 13, pp. 571-585.

Meckbach, R., Jacob, P., Paretzke, H. G., 1988. Gamma exposures due to radionuclides deposited in urban environments. Part I: kerma rates from contaminated urban surfaces. Radiation Protection Dosimetry 25, 167179.

Mück, K., Pröhl, G., Likhtarev, I., Kovgan, L., Meckbach, R. \& Golikov, V., 2002. A consistent radionuclide vector after the Chernobyl accident, Heakth Physics 82(2), pp. 141-156.

Müller, H. \& Pröhl, G., 1993. ECOSYS-87: A dynamic model for assessing radiological consequences of nuclear accidents, Health Physics 64(3), pp. 232-252.

Neal, C., Robson, A.J., Bhardwaj, C.L., Conway, T., Jeffery, H.A., Neal, M., Ryland, G.P., Smith, C.J. \& Walls, J., 1993. Relationships between precipitation, stemflow and throughfall for a lowland beech plantation, blackwood, Hampshire, Southern England - Findings on interception at a forest edge and the effect of storm damage, Journal of Hydrology 146(1-4), pp. 221-233.

Nicholson, K.W., 1988. The dry deposition of small particles - a review of experimental measurementsAtmospheric Environement 22 (12), pp. 2653-2666.Nicholson, K.W. \& Watterson, J.D. (1992). Dry deposition of particulate material onto wheat: in Precipitation Scavenging and Atmosphere-Surface Exchange vol. 2 (edited by Schwartz, S.E. \& Slinn, W.G.N.), Hemisphere, Washington DC, pp. 673-682.

Petroff, A. 2005. Mechanistic study of aerosol dry deposition on vegetated canopies, Radioprotection, Suppl.1, vol. 40, pp. S443-S450.

Pryor, S.C. \& Barthelmie, R.J., 2005. Liquid and chemical fluxes in precipitation, throughfall and stemflow: Observations from a deciduous forest and a red pine plantation in the midwestern USA, Water Air and Soil Pollution 163 (1-4), pp. 203-227.

Reineking, A., Becker, K.H., Porstendörfer, J. \& Wicke, A., 1987. Air activity concentrations and particle size distributions of the Chernobyl aerosol, Radiat. Protect. Dosimetry 19, pp. 159-163.

Ritchie, L.T., 1976. Effects of rainstorms and runoff on consequences of nuclear reactor accidents, Sandia Lab. report SAND76-0429. 
RODOS, 2018. Realtime Online Decision Support System for nuclear emergency management. RODOS system home page, Karlsruhe Institute of Technology, Germany, https://resy5.iket.kit.edu/RODOS/.

Rodriguez, D., van Oijen, M. \& Schapendonk, A.H.M.C., 1999. LINGRA-CC: a sink-source model to simulate the impact of climate change and management on grassland productivity, New Phytol. 144, pp. 359-368.

Roed, J., 1985. Dry deposition of urban surfaces, Risø Report R-515, ISBN 87-550-1069-5.

Roed, J., 1987. Dry deposition in rural and urban areas in Denmark, Rad. Prot. Dos. 21(1/3), pp. 33-36.

Roed, J., 1988. The distribution on trees of dry deposited material from the Chernobyl accident, paper NKA/AKTU-245 (88)2, presented at the Joint CEC/OECD (NEA) Workshop on Recent Advances in Reactor Accident Consequence Assessment, Rome, Italy, 25-30 January 1988.

Roed, J., 1990. Deposition and removal of radioactive substances in an urban area, Final Report of the NKA Project AKTU-245, Nordic Liaison Committee for Atomic Energy at Risø, Denmark, ISBN 8773035149.

Roed, J. \& Jacob, P., 1990. Deposition on urban surfaces and subsequent weathering, Proceedings of a seminar on methods and codes for assessing the off-site consequences of nuclear accidents (vol. 1), Athens, Greece, 1990, EUR13013, pp. 335-356.

Ronneau, C., Cara, J. \& Apers, D., 1987. The deposition of radionuclides from Chernobyl to a forest in Belgium, Atmospheric Environment 21 (6), pp. 1467-1468.

Rulik, P., Bucina, I. \& Malatova, I., 1989. Aerosol particle size distribution in dependence on the type of radionuclide after the Chernobyl accident and in NPP effluents, The Radioecology of Natural and Artificial Radionuclides, Proc. XV Regional Congress of IRPA, Visby, Sweden, Verlag TÜV Rheinland GmbH, Köln, Germany, ISBN 3-88585-668-9.

Salbu, B., 1988. Radionuclides associated with colloids and particles in rainwaters, Oslo, Norway, in: von Philipsborn, H., Steinhäuser, F. (Eds.), Hot particles from the Chernobyl Fallout. Bergbau - und Industrimuseum, Theuern, pp. 83-84.

Salbu, B., 2001. Actinides associated with particles, in: Kudo, A. (Ed.), Plutonium in the environment. Elsevier, Tokyo, pp. 121-138.

Salbu, B., Krekeling, T., Oughton, D.H., Østby, G, Kashparov, V.A., Brand, T.L.\& Day, J.P., 1994. Hot particles in accidental releases from Chernobyl and windscale nuclear installations, Analyst, 199, 125-130.

Sandalls, F.J. \& Gaudern, S.L., 1988. Radiocaesium on urban surfaces in West Cumbria five months after Chernobyl, J. Environ. Radioactivity 7, pp. 87-91.Sartor, J.D., Boyd, G.B. \& Agardy, F.J. (1974). Water pollution aspects of street surface contaminants, Journal WPCF vol. 46, no. 3, pp. 458-466.

Schell, W.R., Linkov, I., Myttenaere, C. \& Morel, B., 1996. A dynamic model for evaluating radionuclide distribution in forests from nuclear accidents, Health Physics 70(3), pp. 318-335.

Schimmack, W., Bunzl, K., Kreutzer, K., Rodenkirchen, E. \& Schierl, R., 1991. Einfluss von Fichte (Picea abies L. Karst) und Buchte (Fagus sylvatica L.) auf die Wanderung von radiocaesium im Boden (in German), Forstwiss Forsch. 39, pp. 242-251 (as referenced by Schell et al., 1996). 
Schwartz, G., 1986. Deposition and post-deposition radionuclide behaviour in urban environments, Proc. Workshop on methods for assessing off-site radiological consequences of nuclear accidents, CEC, Luxemburg, Report EUR 10397 (EN), pp. 533-558.

Sehmel, G.A. 1973. Particle eddy diffusitivities and deposition velocities for isothermal flow and smooth surfaces, Aerosol Science 4, pp. 125-138.

Shaw, S.B., Walter, M.T. \& Steenhuis, T.S., 2006. A physical model of particulate wash-off from rough impervious surfaces, Journal of Hydrology 327, pp. 618-626.

Slinn, W.G.N., 1982. Predictions for particle deposition to vegetative canopies, Atmospheric Environment 16(7), pp. 1785-1794.

Steinhauser, G., 2014. Fukushima's forgotten radionuclides: a review of the understudied radioactive emissions, Environmental Science and Technology 48, 4649-4663.

Tessier, A., Campbell, P.G.C. \& Bisson, M,. 1979. Sequential extraction procedure for the speciation of particulate trace metals, Analytical Chemistry 51, pp. 844-851.

Tschiersch, J. \& Georgi, B., 1987. Chernobyl fallout size distribution in urban areas, J. Aerosol Sci. 18(6), pp. 689-692.

Vargas, A., Camacho, A., Laubenstein, M., Plastino, W., 2016. Dry deposition velocity of Cs-137 and Cs-134 in Spain after the Fukushima Dai-ichi nuclear power plant accident, Applied Radiation and Isotopes, vol. 109, pp. 441-443.

Ver, N., Matus, L., Kunstar, M., Pintér, A., Osán, J., Hózer, Z. \& Tóth, B., 2007. Oxidation and release of ruthenium from white inclusions, European Commission, EUR 22730 EN, ISSN 1018-5593, Luxembourg.

Watterson, J.D. \& Nicholson, K.W.,1996. Dry deposition and interception of 4-22 $\mu \mathrm{m}$ diameter particles to a lettuce crop, J. Aerosol Sci. 27(5), pp. 759-767.

Xiao, Q., McPherson, E.G., Ustin, S.L., Grismer, M.E. \& Simpson, J.R., 2000. Winter rainfall interception by two mature open-grown trees in Davis, California, Hydrological Processes 14, pp. 763-784. 